\title{
Ratooning and perennial staple crops in Malawi. A review
}

\author{
Paul Rogé $e^{1,2}$ (1) Sieglinde Snapp ${ }^{1,3} \cdot$ Mayamiko Nathaniel Kakwera $^{4} \cdot$ Leah Mungai $^{1}$. \\ Isaac Jambo ${ }^{5} \cdot$ Brad Peter $^{1}$
}

Accepted: 20 July 2016/Published online: 6 September 2016

(C) The Author(s) 2016. This article is published with open access at Springerlink.com

\begin{abstract}
The management of staple crops as perennials is a historic legacy and a present-day strategy in some regions of Sub-Saharan Africa, yet perenniality is rarely an agronomic subject. Farmers in Malawi cut annual crops, such as pigeonpea and sorghum, to extend production for more than one growing season. Cassava, a perennial food crop, has a proven track record of abating hunger. Here we review ratooning, as well as the historic role of perennial staple crops in Malawi. Ratooning is a method of harvesting a crop which leaves the roots and the lower parts of the plant uncut to give the ratoon or the stubble crop. This review is completed with interviews with Malawian farmers. The major points follow. The management of staple crops as perennials is underserved by research. Indeed, we retrieved only 86 references on ratooning sorghum and pigeonpea. Of these, $9 \%$ and $19 \%$ respectively were from the African continent. The literature
\end{abstract}

Paul Rogé

proge@berkeley.edu

1 Center for Global Change and Earth Observations, Michigan State University, 218 Manly Miles Building, 1405 S. Harrison Road, East Lansing, MI 48823, USA

2 Present address: Multinational Exchange for Sustainable Agriculture (MESA), University of California, 2362 Bancroft Way \#202, Berkeley, CA 94704, USA

3 Department of Plant, Soil and Microbial Sciences, Michigan State University, 1066 Bogue St., Room 490, East Lansing, MI 48824, USA

4 Lilongwe University of Agriculture and Natural Resources (LUANAR), Bunda Campus, P.O. Box 219, Lilongwi, Malawi

5 University of Wageningen, Wageningen, The Netherlands and interviews indicate that pigeonpea and sorghum have high productive potential when well managed in ratoon systems. Thirty-five percent of interviewee responses that supported ratooning mentioned saving seed. Other primary reasons to ratoon include stimulating regrowth $(30 \%)$ and saving labor $(20 \%)$. However, $31 \%$ of responses that were against ratooning cited increased disease potential, as well as excessive vegetative regrowth $(18 \%)$.

Keywords Africa $\cdot$ Agroecology $\cdot$ Malawi $\cdot$ Perennial staple crops $\cdot$ Ratooning

\section{Contents}

1. Introduction

1.1. A review of the literature on ratooning

1.1.1. Ratooned sorghum

1.1.2. Ratooned pigeonpea

1.2. Perennial staple crops in Malawi

2. Case study approach

3. Farmer interviews

3.1. Perennial staple crops in Malawi

3.2. The use and management of perennial staple crops

4. A pathway for action and research

4.1. Community level

4.2. Crop-specific research needs

5. Conclusion

\section{Introduction}

Perenniality in mixed cropping systems is rarely an agronomic subject, as is demonstrated by comparatively modest research on the breeding of perennial grains (Kane et al. 2016) and on permaculture (Ferguson and Lovell 2014). In reality, small 
farmers around the world already resist simplified models of agriculture by diversifying their farms (Altieri 2004; Altieri and Toledo 2011). The central motivation of our review is to consider options for shifting agronomic research from models focused on monoculture production of short duration crop types toward those focused on the integration of perennial and annual species in mixed cropping systems.

The cultivation and wild harvesting of perennial foods is a historic legacy and a present-day strategy in some regions of Sub-Saharan Africa (see Harlan 1989a, b; NRC 1996; Batello et al. 2004, 2014). For the purposes of this article, we consider crops that may be managed to produce harvests for more than one rainy season as exhibiting perennial attributes. These attributes are present in several important African food crops such as sorghum (Sorghum bicolor [L.] Moench), pigeonpea (Cajanus cajan [L.] Millsp.), and cassava (Manihot esculenta). Our interest is primarily in perennial grains, but we include cassava because it is commonly grown for more than one rainy season.

Our study begins with a review of the literature on ratooning pigeonpea and sorghum. Ratooning is the cultural practice of cutting crops near their crown after a first harvest of grain or fodder (Fig. 1). This permits crops such as sorghum, pearl millet, and pigeonpea to grow back for subsequent harvests of grain or animal forage (NRC 1996). We also discuss the historic contributions of perennial attributes to environmental sustainability and food security in Malawi. In order to strengthen the limited research on ratooning generally and on the role of perenniality in Malawian food systems, we reflect on interviews with Malawian farmers about the use of perennial staple crops under largely rainfed and marginal conditions. Are perennial staple crops grown in particular agricultural environments or under certain social contexts? In comparison with annuals, perennials may exhibit different pests and diseases, market potential, timing of production, and spatial arrangements. We highlight how perennial staple crops already contribute to the agricultural objectives of Malawian farmers. Finally, we discuss opportunities for action and research to develop the potential of perennial staple crops.

\subsection{A review of the literature on ratooning}

There is little research on the cultural practice of ratooning sorghum and pigeonpea. A search of four prominent bibliographic databases retrieved 66 relevant references on the ratooning of sorghum and 20 relevant references on the ratooning of pigeonpea. Kane et al. (2016) explain how this search was conducted. Of the references whose location could be determined, the majority of research on ratooning sorghum and pigeonpea came from India (40 and $81 \%$, respectively; Table 1). The United States and Australia have contributed some research on ratooning sorghum (22 and $9 \%$, respectively). Very little research on ratooning sorghum and pigeonpea comes from the African continent (9 and $19 \%$ respectively) even though

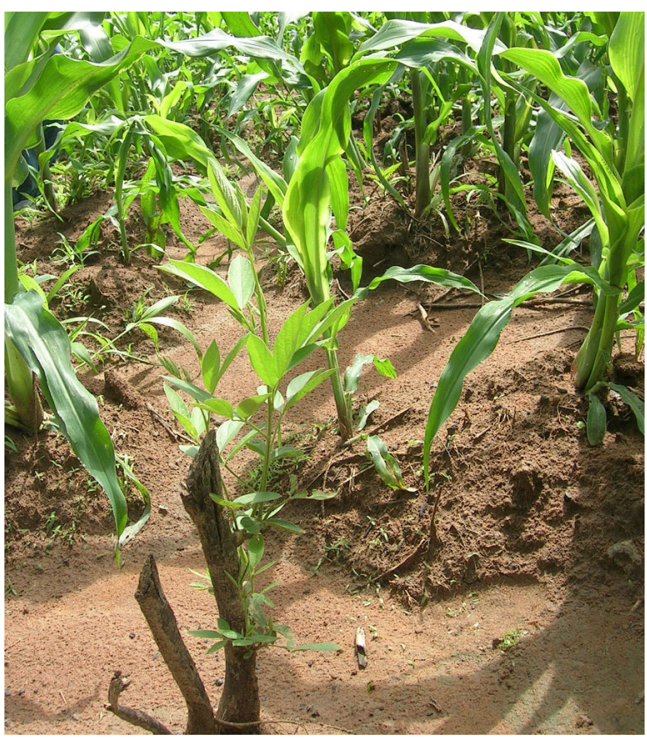

Fig. 1 A photo of ratooned pigeonpea regrowing for a second year in a maize field in Malawi. Note that the pigeonpea was ratooned with an angular cut using a panga knife at an approximate height of $30 \mathrm{~cm}$. Additionally, it is of interest to observe that farmers often shift their ridges from one year to the next, and therefore pigeonpea that was planted on top of the ridge in the first year will end up in the pathway between ridges in the second year

Africa is a center of diversity for these crops. We begin by reflecting on the primary issues and research findings globally given limited prior research. Later sections present a research agenda on perennial staple crops for the southern and eastern Africa region that includes the important cultural practice of ratooning.

Table 1 The count of journal articles on the practice of ratooning sorghum and pigeonpea. References were retrieved from a search of five bibliographic databases (see Kane et al. 2016). Counts and percentages reflect only those articles that had sufficient bibliographic information to determine the location of the study

\begin{tabular}{llll}
\hline Crop & Country or region & Count & Percentage \\
\hline \multirow{2}{*}{ sorghum } & India & 22 & 40 \\
& United States & 12 & 22 \\
& Australia & 5 & 9 \\
& South Africa & 3 & 5 \\
& Taiwan & 3 & 5 \\
& Brazil & 2 & 4 \\
& Canada & 2 & 4 \\
& China & 2 & 4 \\
& Ethiopia & 1 & 2 \\
& Pakistan & 1 & 2 \\
& Philippines & 1 & 2 \\
& Tanzania & 1 & 2 \\
& India & 13 & 81 \\
& Nigeria & 2 & 12 \\
& southern and eastern Africa & 1 & 6 \\
\hline
\end{tabular}




\subsubsection{Ratooned sorghum}

Breeding and selection of sorghum for ratooning systems is sparse. The earliest scientific literature on ratooning has promoted it as a method used for seed selection of outcrossed seed stock (Parmornchantr 1966). It was not until the 1980s that tiller regrowth of a ratoon crop was used as a measure of nonsenescence and was found to be quantitatively inherited with additive genetic effects and no indication of significant dominance genetic effects (Duncan et al. 1980). More recently, the genes commonly expressed in rhizomes were identified to find possible relatedness between rhizomatous and ratooning quantitative trait loci that may be a result of ancient duplication (Jang et al. 2006). Areas highlighted for breeding include ratoon cultivar types with pest resistance and with increased plant weight production of the ratoon crop (Duncan and Gardner 1984). Although varietal adaptability is important (Goodroad and Duncan 1988), breeding efforts to stabilize ratoon crop yields may even be more so (Duncan and Moss 1987). Early duration varieties may help the ratoon crop avoid drought (Bapat and Shinde 1978), but mediummaturity sorghum hybrids have been found to out-yield the early group by $2.70 \mathrm{t}$ grain/ha and the late group by $1.90 \mathrm{t}$ grain/ha (Duncan 1979). Only one study found that planting sorghum hybrids out-yielded ratooned sorghum in terms of grain and fodder over a three year period (Gaikwad et al. 1984).

Ratooning sorghum is primarily a water management strategy in southern and eastern Africa. In Ethiopia, a center of origin and diversity for sorghum, $30 \%$ of farmers practiced ratooning mostly due to drought (71 \%), but also pests (26\%; Mekbib 2009). Studies have shown that ratooned sorghum has high production stability in both below and above average rainfall years under semi-arid conditions (Brahmbhatt and Patel 1983). This perspective runs contrary to the hydrologic and crop growth models of ratooned grain sorghum in the Central Texas Badlands that predicted inadequate yields with normal water levels (Stinson et al. 1981). These water shortfalls for ratooned sorghum production might be mitigated by recommendations from agronomic research on critical stages for irrigation to ensure optimal yields and high water use efficiency (Patel et al. 1989), such as at flowering (Subramanian et al. 1986).

Diseases, such as the fungus Colletotrichum graminicola (Bergquist 1973), and insect pests, such as the fall armyworm (Spodoptera frugiperda Smith; Duncan and Gardner 1984), appear to be more severe on ratoon sorghum. For example, a study in India found that Atherigona soccata (Rond.) caused particularly substantial losses of grain and fodder in the ratoon crop (Mote et al. 1982). The only abundant pest of sorghum identified by Mote (1983) was A. soccata, which caused the most losses in grain and fodder production for the ratoon crop in comparison to the rainy season and winter crops. More specific to our region of interest, stem borer Chilo partellus (Swinhoe) has expanded its range in the low-altitude regions of eastern and southern Africa since its first detection in 1932 in part because of its efficiency in colonizing ratooned sorghum, thus outcompeting the stem borer Busseola fusca (Fuller) that was already present in the region (Kfir 1997). In South Africa, the first generation of $C$. partellus was found to only infest early grain sorghum tillers from a ratoon crop (Kfir 1992). Larval parasitism, mostly by Cotesia sesamiae, usually lags behind the peak larval population of even the native $B$. fusca in the ratooned sorghum crops of South Africa (Kfir and Bell 1993).

Management choices appear to greatly influence the grain yields from ratooned sorghum, which suggests that high sorghum yields are possible with good management (Wade et al. 1992). Research in northern India found that ratoon crops produced more fresh fodder and grain than late sown sorghum (Pal and Kaushik 1969), which was attributed to increased tillering. However, the ratoon crop may produce more biomass but less seed production than the original crop (Rao and Damodaram 1972). The cutting height may influence these outcomes, since cutting at $3 \mathrm{~cm}$ can lead to infection by disease organisms and higher cuttings at $13 \mathrm{~cm}$ can affect the ability of adventitious roots to reach the ground (Escalada 1974). Most research agrees that ratooning sorghum at a high height increases the production of shoots (Rao and Damodaram 1972), achieves more uniform tiller production (Escalada 1974), and obtains the best grain and biomass production (Mackenzie et al. 1970; Escalada 1974; Foloni et al. 2008). However, these experiments compared different cutting heights: $100 \mathrm{~cm}$ versus $20 \mathrm{~cm}$ (Mackenzie et al. 1970); $22.5 \mathrm{~cm}$ versus 10 and $15 \mathrm{~cm}$ (Rao and Damodaram 1972); $8 \mathrm{~cm}$ versus $3 \mathrm{~cm}$ (Escalada 1974); and $36 \mathrm{~cm}$ versus $13 \mathrm{~cm}$ (Foloni et al. 2008).

Advanced planning may greatly increase the economic success of ratooned sorghum by lowering establishment costs, increasing rainwater efficiency, and reducing soil erosion (Calderwood et al. 1996). Aguiar (1981) argues that the overall yield from three years of annual sorghum ratooning planted in Brazil is technically viable even though grain yields decreased from the original harvest to the two subsequent ratoon croppings. Foale and Carberry (1996) propose that the flexibility of sorghum, including its ratooning ability, makes it a good candidate for on-farm cropping research that aims to reduce farmers' level of risk. However, cropping systems research involving ratooning sorghum has thus far occurred on research stations. Numerous potential cropping systems that include ratooned sorghum have been identified with positive productivity outcomes (Dunavin 1975; Ramshe et al. 1985; Asokaraja and Ramiah 1988; Brunson and Griffin 1988; Chen and Yein 2005). However, ratooned sorghum was not found to be part of the most productive or economically viable cropping system tested in some cases (Pawar and Thaval 1984; Reddy and Willey 1985; Arunachalam et al. 1993).

The positive effects of applying organic or synthetic fertilizers to ratooned sorghum include reducing days to flowering (Molina et al. 1977), and in one case producing more grain yield than the original crop (Balasubramaniam and Manickasundram 1993). Various other studies have identified 
the most productive and economical combinations of fertilizers for ratooned sorghum (Touchton and Martin 1981; Lomte and Dabhade 1990; Huang et al. 1992). Some of these studies were conducted in irrigated conditions (Lomte and Dabhade 1990), or in combination with pesticides (Touchton and Martin 1981). However, cropping arrangement may be more critical than fertilization regimes (Bhat and Hosmani 1993).

\subsubsection{Ratooned pigeonpea}

Very little research has been done to select pigeonpea cultivars for ratoon crops. Gwata and Silim (2009) developed three pigeonpea cultivars for southern and eastern Africa that are compatible with ratooning, however no yield or ratooning comparisons were reported. A high variability in yields from the ratoon crop suggests that more selection is needed for yield stability (Sharma et al. 1978). One possible selection indicator may be high leaf area retention in the original crop, as was observed for short duration pigeonpea varieties in Andhra Pradesh, India (Chauhan et al. 1996).

The ratoon crop of pigeonpea generally produces less than the original crop depending on environmental conditions, but with minimal additional effort. The number of possible harvests, as well as the most productive varieties and planting density, were found to be site specific in India (Chauhan et al. 1984a). For example, reported second harvests from pigeonpea was generally higher for non-ratooned crops than ratooned crops, and the yield potential of the second harvest was greater on Alfisols with one watering than on Vertisols (Venkataratnam and Sheldrake 1985). Even when pigeonpea planted in Vertisol soils suffered attacks from Rhizoctonia bataticola in the dry season, the crops managed to recover in the Monsoon rains, thus producing two subsequent smaller yields, but with minimal additional effort (Chauhan et al. 1984b).

However, there have also been reports that a bushy pigeonpea genotype planted in an Alfisol under semi-arid conditions produced more grain yields in the ratoon crop compared to the original crop regardless of whether or not the crops received micrositing with water or castor cake treatment (Nimbole 1997). Ratooned pigeonpea was found to facilitate cross-pollination between early and medium flowering cultivars (Saxena et al. 1976). Additionally, less flower fall was seen on ratooned early maturing pigeonpea than on nonratooned crops. Moreover, the differences in grain yield between the main and ratoon crops have been found to differ more when grown on large plots than on small plots (Johansen et al. 1991). Thus, the productivity of ratooned pigeonpea may be largely environmentally dependent.

More investigation is needed on the benefits and drawbacks of different harvesting and ratooning strategies for pigeonpea. In Nigeria, a dwarf pigeonpea variety produced more after two ratoonings when cut at a low height $(30 \mathrm{~cm})$ than at a high height $(60 \mathrm{~cm})$, however both ratooning heights performed better than crops that were left intact (Tayo 1985). This differs from a study in India that reported the best yields for a short duration pigeonpea were obtained using a full recommended dose of fertilizer and ratooning by plucking the pods rather than cutting (Mahale et al. 1997).

More research is also needed on cropping systems since those involving ratooned pigeonpea were not always found to be the most productive (Yadava and Yadav 1995; Maheshwari et al. 1997). Yadav and Yadav (1991) reported that increasing plant densities decreases yields in the ratoon crop by a third of the orginial harvest. Nevertheless, studies found that cropping systems with ratooned pigeonpea had the highest benefit:cost ratio (Yadav and Yadav 1992, 1995).

Studies on disease and pests of ratooned pigeonpea appear to be much less prevalent than for sorghum. Pandey and Singh (2000) determined that ratooning was unfeasable based on high rainfall years that provoked diseases and excessive plant growth. However, the more resistant genotypes to fusarium wilt have been shown to produce twice as much grain in the second season compared to the first (Reddy and Raju 1997a). In a study from Nigeria, significant seed damage caused by Clavigralla spp. during the reproductive phase of both the original and ratoon crops of pigeonpea was somewhat mediated by intercropping with maize even though overall pigeonpea yields still dropped due the intercropping effect (Dasbak et al. 2012). Moreover, the genotypes of pigeonpea exhibited different pest resistance and grain yields.

\subsection{Perennial staple crops in Malawi}

The scientific literature on ratooning sorghum and pigeonpea clearly shows the limited quantity of research on ratooning sorghum and pigeonpea generally, as well as in southern and eastern Africa. We therefore draw on a wider body of literature to highlight the historic importance of perennial staple crops in Malawi. The history of agricultural policies shows a persistent assumption that soil degradation and human population are the principal causes of food shortages and the determinants of sustainability. The presumption that indigenous practices are not sufficiently productive or effective at protecting soil is complex, and is intertwined with Colonial attitudes toward African farmers and perceived causes of food shortage. We explore some of the history, and consequences for smallholder farming systems in Malawi today.

Food security and land degradation in Malawi is partly a legacy of Colonial policies that discouraged indigenous practices, such as the cultivation of sorghum and pigeonpea. Intercropping is one of the oldest indigenous techniques of crop production in tropical Africa. In Malawi, intercropping increases the chances of obtaining a harvest, improves soil fertility, and maximizes the returns to labor by harvesting multiple crops from the same piece of cleared land (Mulwafu 2011). Indigenous soil conservation strategies - planting outer ridges 
with trees and grass, planting bananas on contour, and building stone borders - also contribute to sustained yields. These indigenous strategies reduce soil losses, increase soil fertility, and enhance the infiltration and water holding capacities of soils. To this day, stone lines are widely used in steeper areas of Malawi, particularly in remote areas where indigenous knowledge is more prominent (Kanyama-Phiri et al. 2000).

Colonial Era conservation projects transformed interactions between small farmers and the environment. Prior to World War II, governments around the world promoted soil conservation strategies due to concerns that were heightened by the dust storms of the American Dust Bowl. However, in Malawi there was little credence given to indigenous systems of knowledge (Mulwafu 2011). Conservation laws instead required the implementation of techniques that were developed by the Imperial Forestry Institute (IFI) of Oxford, such as contour ridging, box ridging, bunding, and terracing. Not surprisingly, labor-intensive soil conservation laws were unpopular with farmers, and enforcement often involved coercion in the form of penalty fines and physical punishment.

The Colonial Department of Agriculture also prosecuted farmers who cultivated along rivers, who grew polycultures, or who grew hardy perennial sorghum (Vaughan 1987). A vision of modern agriculture was promoted based on the monoculture production of maize (Mulwafu 2011). Sorghum was described by Buchanan (1885) in such terms:

"Sorghum or Kaffir corn is grown chiefly on the river, and in some places in Zomba... Sorghum has the advantage of being biennial: it may even be used for three years, but the third crop is apt to be poor and blanky [sic]. The grain is easier converted to flour than maize: the plant, too, though growing to an immense height - often 12 feet - when the soil is good, will yield a fair return in thin shingly soil that would not support maize. The roots of sorghum are of a stronger character, and go farther in search of food."

In 1949, the Southern Province of Malawi experienced a severe famine when maize crops failed. However, the famine was in fact one hundred years in the making rather than a "subsistence crisis" (Vaughan 1987). Across the Southern Province, there was high variability in the degree of food shortage; wetland maize and drought-resistant crops, like ratooned sorghum, produced well (Vaughan 1987). Fortunately, farmers did not universally adopt the Department of Agriculture's earlier campaign against the cultivation of such hardy crops, which provided populations with options for local famine relief (Vaughan 1987).

Sorghum and root crops received more attention from the Department of Agriculture following the famine of 1949 because of their contribution to abating hunger. Blantyre produced a surplus of sorghum in the $1950 \mathrm{~s}$ and Indian traders fostered a cash crop industry for the production of pulses (Vaughan 1987) that likely included pigeonpea. An official sorghum market was established, and farmers increased the production of cassava and the cultivation of wetlands.

Fifty-three years later in 2002, Malawi experienced its next food crisis that once again was not solely due to failures of production. Between 300 and 3000 Malawians are estimated to have died of starvation and diseases related to hunger (Devereux 2002). The national production of maize had fallen by $32 \%$ from a record high of 2.5 million metric tons in the $1999 / 2000$ season to 1.7 metric tons in 2000/2001 due to high rainfall that waterlogged fields. Officials initially explained local maize shortages and increased market prices as the result of Malawian's "inflexible eating habits" and "strong consumption preference for maize" even though many Malawians relocated to cassava growing areas for food.

Additionally, a decade earlier in 1991/92, a severe drought had reduced maize production in Malawi by less than half of the 2001/02 harvest but with less severe consequences (Eldridge 2002). The 2002 crisis was provoked by the increased vulnerability of poor and rural populations to natural disasters due to declining soil fertility, shrinking landholdings, and increasing rates of HIV/AIDS infection (Devereux 2002). Notably, life expectancy had decreased from 51 to 37 years by 1999, which resulted in severe constraints on adult labor (Haacker 2002).

Moreover, agricultural trade liberalization weakened national institutions, and consequently increased the exposure of Malawians to failures in production, markets, and relief support (Devereux 2002). The Malawian government had compromised its ability to respond to the crisis when it sold its Strategic Grain Reserve (SGR) to Kenya and Mozambique between April - May 2001. The International Monetary Fund (IMF) had encouraged Malawi to sell part of its SGR to pay for its debts. Malawi had harvested bumper maize yields in the two previous seasons that could have very well averted the crisis.

\section{Case study approach}

Malawi's agricultural history forms the basis for our interest in the farmers' experiences with perennial staple crops. We used semi-structured interviews to better understand the importance of perenniality and to assess the potential for future research. We spoke with 48 farmers between July - August of 2014 from 4 villages in each of the Northern, Central, and Southern Regions (Fig. 2). Four interviews were conducted per village for a total of 16 interviews per Region. Specifically, we visited the Districts of Mzimba (Northern Region), Kasungu (Central Region), and Zomba (Southern 
Region). ${ }^{1}$ Each interview was with a member from a different household, and we balanced the number of interviews between women and men. We also spoke with at least two farmers per village who had grown perennial staple crops during the 2013/14 rainy season.

These sites have distinct histories of producing perennial staple crops. Notably, soil improvement and food security projects have introduced pigeonpea in the past 10 years to villages in the Central and Northern Regions (Snapp et al. 2010). We also learned through the course of our fieldwork that the distribution of pigeonpea was facilitated by agricultural extension agents to neighboring villages. We selected Mzimba and Kasungu villages within $8 \mathrm{~km}$ of where projects had introduced pigeonpea. In contrast, pigeonpea and sorghum have been historically produced in the Southern Region.

An additional criterion for the selection of villages was the mean peak growing season (February-March) Normalized Difference Vegetation Index (NDVI) from 2003 to 2010. NDVI was used as an indicator of vegetation productivity. We generated the NDVI grid and clipped it to correspond with areas that were classified as agriculture by at least four out of eight land-use classification systems (Messina et al. 2014). We selected two villages in each Region with relatively low NDVI values and two villages in each Region with relatively high NDVI values. Since our interviews were not associated directly with any particular plot, we targeted villages that were located in areas with generally low or high NDVI rather than specific pixels with extreme values. However, clear distinctions were not apparent while in the field or during data analysis.

As a semi-structured approach, we developed an initial set of questions in advance that provided a flexible structure to guide conversations with farmers. We tested the questions with farmers in Mzimba before starting the research campaign. However, the guiding questions continued to evolve based on informant feedback and unanticipated dimensions. Responses to follow-up and clarifying questions that emerged during the interviews were also documented. This article primarily relies on information obtained about the role of perennial staple crops in Malawian farming systems and the cultural practices associated with crop cycles extending through the dry season (themes 1 and 2 in Table 2).

The information from farmers was detail-rich yet lacking the consistency and volume that is common for more structured surveys. The figures presented in this article are created from queries on the qualitative responses from farmers. The counts of responses are therefore quite uneven across Districts. The most obvious case is Fig. 7 for which the

\footnotetext{
${ }^{1}$ The villages of: Msekeni Kawelani, Yachim Ngwira, Yesaya Jere, and Mkowela Mhlanga near Ekwendeni (Mzimba District, Northern Region); Ndaya, Kadoda, Nsalale, Mbale, Makhalangala, and Tembo in the Mpokwa Extension Planning Area (Kasungu District, Central Region); and Mulenga II, Mwaliwa, Sitima II, and Nasasala in the Simlemba Extension Planning Area (Zomba District, Southern Region).
}

question of why farmers did not ratoon was only asked in Zomba. The total count of responses from each District are noted in the figure captions. This approach attempts to facilitate visual comparisons of responses between Districts.

\section{Farmer interviews}

Maize is the most common grain crop produced for food and sale (Fig. 3). Farmers grow both local and hybrid varieties. Farmers sell crops when they face monetary expenses or when there is an increase in market prices. Cassava, groundnuts (peanuts), and soy are grown in all three Districts, but production for sale is common in Mzimba. Various commercial outlets for groundnuts and soy exist in Mzimba, including the Ekwendeni hospital. The agricultural economies of Kasungu are notably focused on tobacco, and to a lesser extent in Mzimba. Development projects promoted pigeonpea in the Northern and Central Regions, but a commercial market has yet to develop. Consequently, farmers that we interviewed sell pigeonpea within their villages. In Zomba, pigeonpea is widely grown for sale to Indian-owned export companies such as AGORA and Rab Processors. Sorghum and finger millet is sold to local brewing companies. Rice production also distinguishes Zomba from the other two Districts.

In the last 10 years, farmers have experienced climatic hardships such as heavy, erratic, and inadequate rainfall. Three farmers in Kasungu associated these climatic hardships with the cutting down of trees that exposes soils to the elements. In Mzimba and Zomba, interviewees reported that heavy rains wash away crops such as tobacco, groundnuts, and maize. The combination of high rainfall and fertilizer applications also increases the risk that maize stalks will collapse (called lodging). Short and erratic rainy seasons have affected the timing of planting, which in turn reduces the yields obtained from crops like maize and tobacco. Farmers increasingly adopt early-maturing hybrid maize and have shifted sowing dates from mid-November to early December because of delays in the start of the rainy season.

Farmers measure food shortage in terms of maize. Sixty-six percent of interviewees in the three Districts experience maize shortages for different lengths of time between January - April. Acute shortages usually occur for one month between January - March. In rare cases, farmers go without maize for 2-5 months. Across the Districts, farmers use income from farming or alternative economic activities to purchase maize. Families sell crops such as cassava, pigeonpea, soy, tobacco, and horticultural crops from wetland plots. In Mzimba and Kasungu, farmers purchase maize on credit for future tobacco sales. Income for purchasing maize comes from casual labor, livestock sales, trade, and commerce. Maize is procured from non-governmental organizations, the Agricultural Development and Marketing Corporation (ADMARC), or other formal and informal sources. 


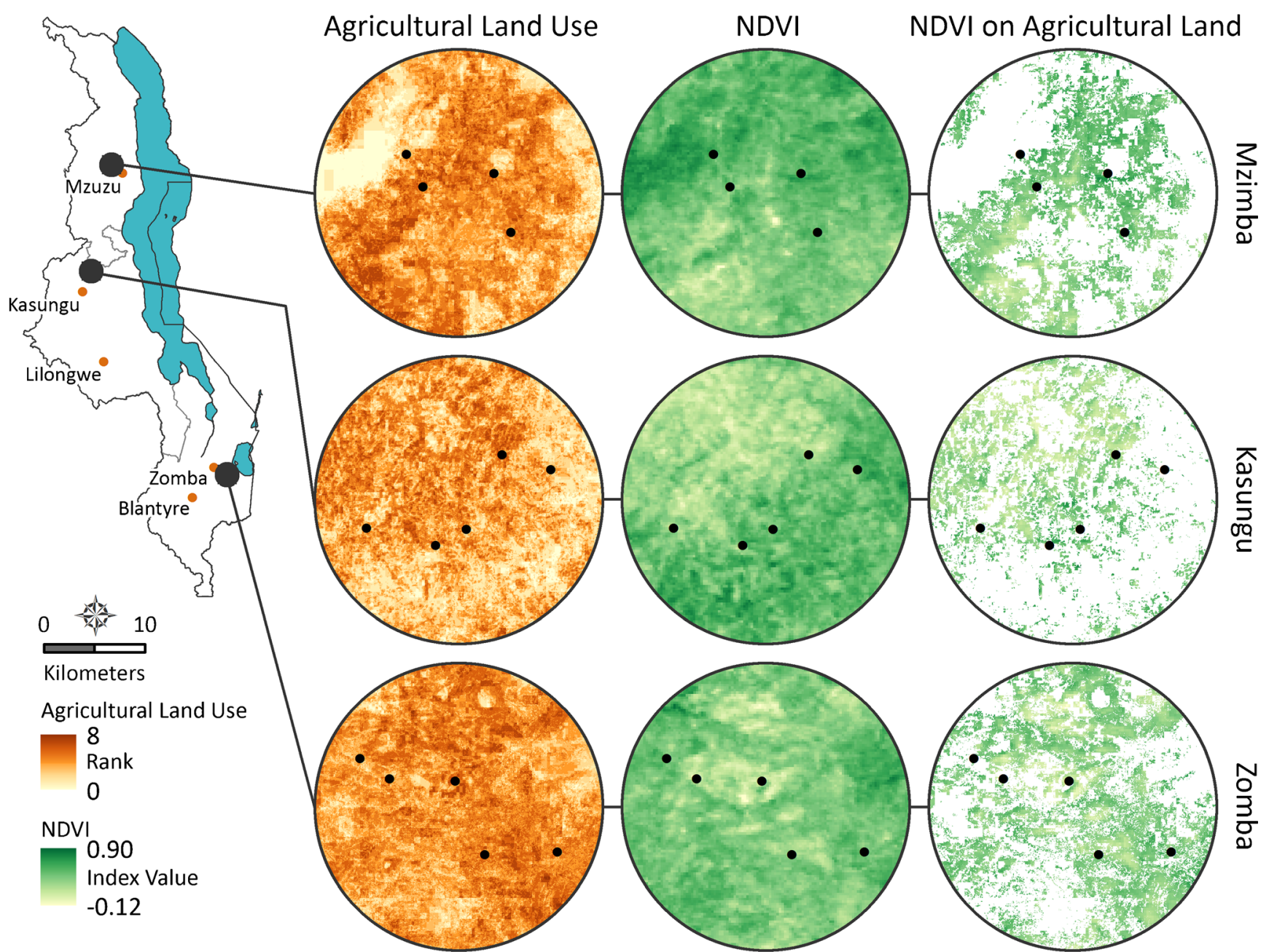

Fig. 2 A map of the sample villages in the Districts of Mzimba, Kasungu, and Zomba of Malawi. The map illustrates (1) mean peak growing season (February-March) Normalized Difference Vegetation Index (NDVI) from 2003 to 2010 in each region, (2) agricultural land-use, and (3) NDVI on agricultural land only. The agricultural land-use map shows the degree of overlap between eight different classification systems. A rank of eight indicates that all eight datasets agree that a particular area is agriculture,

\subsection{Perennial staple crops in Malawi}

According to the farmers that we interviewed, Malawi has favorable climatic and soil conditions for perennial staple crops. Pigeonpea, sorghum, and cassava tolerate poor soils, but perform best in favorable conditions. Perennial staple crops benefit from soils that retain moisture in the dry season, which are associated with fertile/loamy textures and fields with relatively flat slopes in close proximity to rivers. Farmers manage soil moisture by (1) constructing field borders with vetiver grass, (2) planting crops like pigeonpea that shade the soil, (3) box ridging, (4) contour bunds and swales, (5) cover cropping with cowpea, and (6) applying crop residues and manures. Conservation agriculture was mentioned by several farmers as a recently introduced strategy that includes zero tillage and covering fields with maize stalks. All of these strategies are

and a rank of zero indicates areas where none of the datasets classify a particular area as agriculture. Data sources: NDVI from LP DAAC (2000a) and agricultural land-use from LP DAAC (2000b), European Space Agency (2000), European Space Agency (2005), European Space Agency (2010), Brown et al. (2009), MASDAP (1990), MASDAP (2000), and MASDAP (2010)

intended to retain soil moisture during the rainy season, although their effects may carry over to the dry season.

Conflicts with livestock herding is the major constraint for perennial grain production (Fig. 4). In Mzimba and Kasungu, animal husbandry presents an important barrier to the production of perennial crops. Livestock are traditionally released to feed on crop residues after the maize harvest, which occurs between July - August. Poorly monitored livestock cause damage to those crops that are still growing. Pigeonpea is the most commonly damaged crop by livestock, followed by maize, cassava, sorghum, and soy. Furthermore, the risk of crop damage and theft is a reason to produce perennial grain crops either close to the homestead where they can be monitored, or far from the village where animals are not grazed. Other issues include small landholdings, lack of developed markets, labor shortages, and lack of seed availability. 
Table 2 The guiding questions for semi-structured interviews in roughly the order that the enumerators posed them. As a semi-structured interview methodology, the exact phrasing and order of the questions varied across the interviews. The guiding questions were grouped around four themes that related to our study objectives: (1) the role of perennial staple crops in Malawian farming systems; (2) the cultural practices associated with crop cycles extending through the dry season; (3) farmer logic for placing crops in available fields; and (4) the crop and variety choices of farmers. The interviews began with having farmers map their fields, noting size, rank, and crops grown in the 2013-2014 season

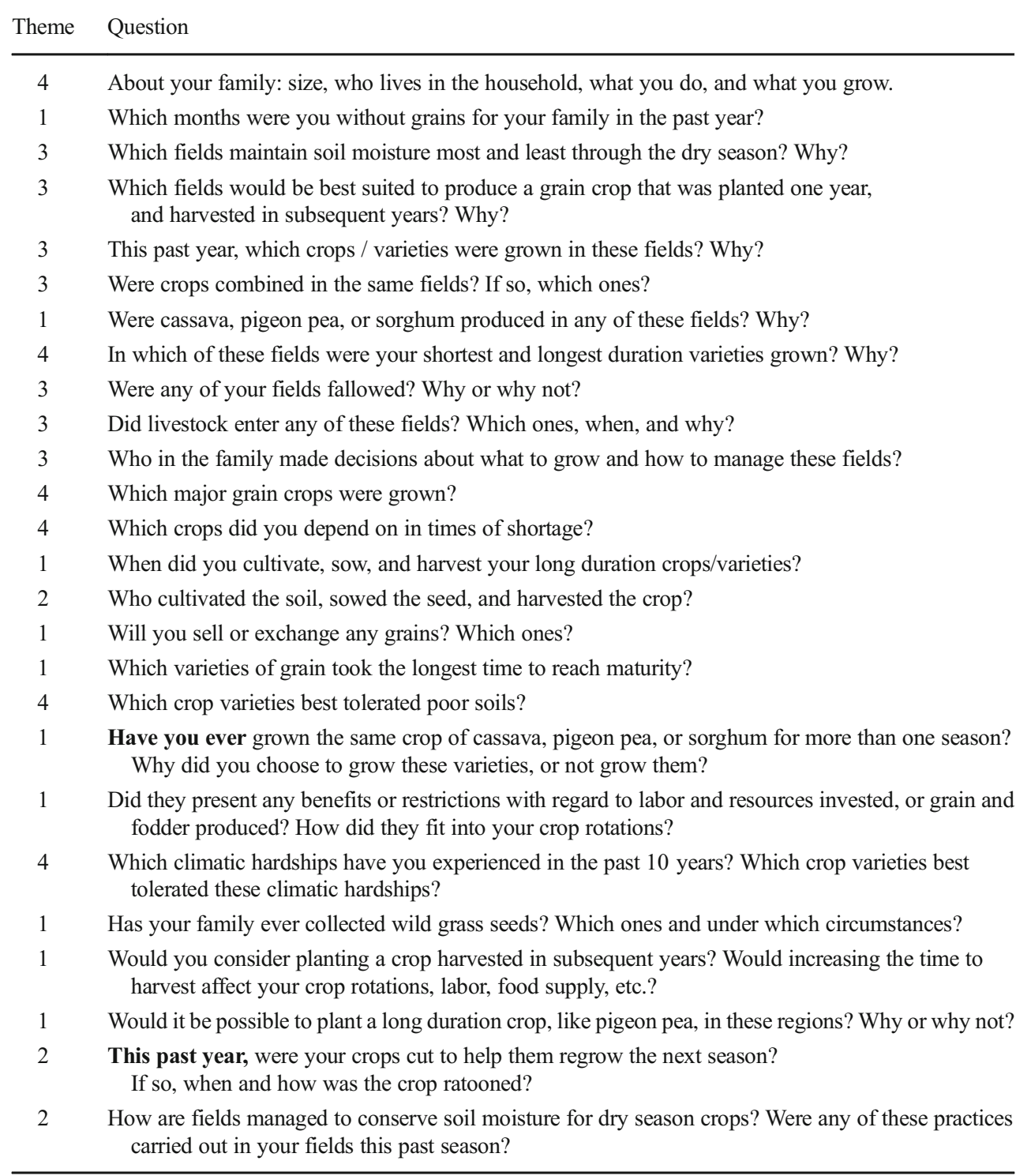

Villages that we visited in Mzimba and Kasungu had recently passed ordinances aimed at protecting crops from livestock year-round since families are increasingly producing cassava and pigeonpea. Strategies include prohibiting free pasture and designating dedicated areas to graze animals. Interviewees still expressed concern about growing crops like pigeonpea for more than one year due to hesitance to confront neighbors when such issues arise. Despite the ordinances, farmers expect village headmen to side with families that keep livestock. Zomba farmers experience less issues with damaged crops from livestock than farmers in Mzimba and Kasungu. Half of the interviewees in Zomba described community-based bylaws for the protection of crops. This may be due to a history of producing perennial pigeonpea and sorghum in addition to smaller landholdings that require a supervised management of livestock.
Perennial staple crops are most commonly grown for family consumption and for market (Fig. 5). In addition, Mzimba and Kasungu farmers use perennials to improve the quality of their soils for maize and other cash crops. For example, the fixation of atmospheric nitrogen and leafy groundcover from pigeonpea contributes to reduced fertilizer inputs and improved maize yields. In these Districts, cassava and pigeonpea are the first crops sown after a fallow period to improve the soil structure for other crops such as tobacco or groundnuts. Pigeonpea and cassava are thought to improve soil fertility and rainwater infiltration. Farmers in Mzimba intercrop with perennial and annual crops to save labor and to increase fertilizer use efficiency. Intercropping annual and perennial crops reduces labor since cultural practices such as soil cultivation, mounding, and weeding are applied simultaneously. Pigeonpea, cassava, and sorghum are often planted as borders between fields in all three Districts. 
Fig. 3 A histogram of crops that farmers in the Malawian Districts of (a) Mzimba (green), (b)

Kasungu (orange), and (c) Zomba (purple) reported growing in 2013-2014. There were 86, 92, and 78 responses, respectively. A total of 256 data entries were recorded from the 48 interviews

Fig. 4 A histogram of the constraints for growing perennial staple crops reported by farmers in the Malawian Districts of (a) Mzimba (green), (b) Kasungu (orange), and (c) Zomba (purple). There were 7 responses in each District. A total of 21 data entries were recorded from the 48 interviews
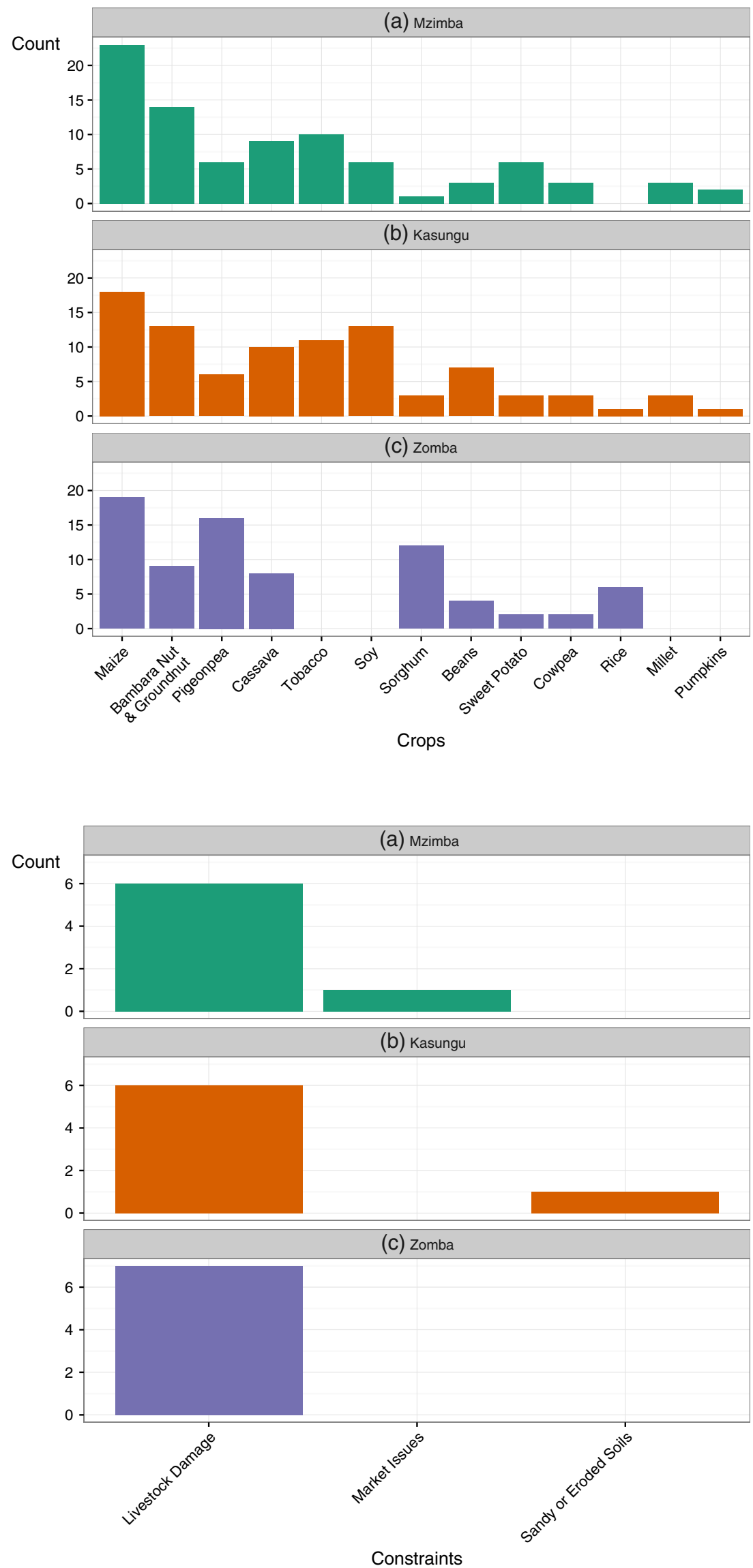

Constraints 
Fig. 5 A histogram of farmers' production goals for perennial staple crops in the Malawian Districts of (a) Mzimba (green), (b) Kasungu (orange), and (c) Zomba (purple). There were 26, 20 , and 25 responses, respectively. A total of 71 data entries were recorded from the 48 interviews

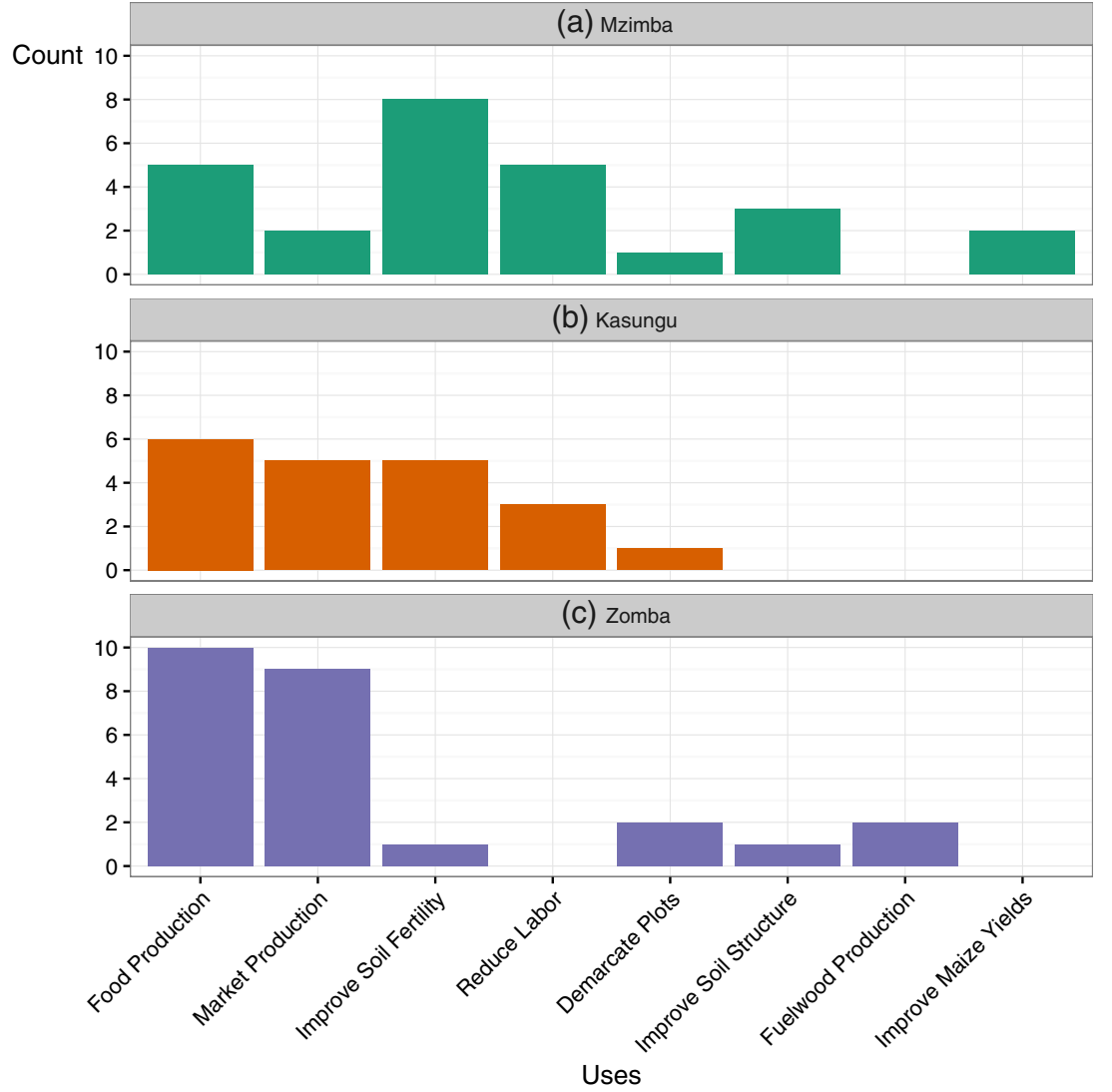

Fallows in Mzimba and Kasungu are used to improve soil fertility (Fig. 6). Fields may also be set aside for the children of the family to cultivate when they come of age. Fallows are used for various resources, such as fuelwood, thatch grass, and construction poles. In contrast, farmers from Zomba do not practice fallowing due to a shortage of land.

\subsection{The use and management of perennial staple crops}

To follow, we present how perennial pigeonpea, sorghum, and cassava are currently used and managed in Malawi. Pigeonpea is eaten locally as a side dish alongside the staple dish typically prepared from maize (i.e., nsima). Farmers grow pigeonpea for more than one season to increase grain yields in subsequent years, to improve soil fertility, to conserve labor, to reduce external inputs, and to produce more biomass for fuelwood. Maize crops that follow perennial pigeonpea grow faster and achieve acceptable yields with less fertilizer. A particularly effective way for farmers to improve the fertility of their soils is by intercropping groundnuts with pigeonpea, commonly referred to as doubled-up legumes.

Ratooning pigeonpea saves labor and seed at sowing time. Grain yields from ratooned pigeonpea also increase, as does biomass for fuelwood. In the three Districts, pigeonpea is sown from December - January for a harvest from April - July. Zomba farmers begin harvesting fresh pigeonpea as early as
March. Pigeonpea is ratooned before the first rains from October - December or during the harvest period from June August. The branches are cut at $30-60 \mathrm{~cm}$ above the soil surface using a Panga knife or by hand. Thirty percent of responses in favor of ratooning indicated that ratooning stimulates regrowth (Fig. 7). Ratooning was also mentioned as a preventative measure to prevent excessively shading annual companion crops such as maize (5\% of responses in support of ratooning). Some farmers apparently are more interested in the yields from maize than from perennial pigeonpea or sorghum; $18 \%$ of the responses not in favor of ratooning that the pigeonpea and sorghum regrowth produces an abundance of vegetation to the detriment of maize. Notably, interactions between livestock and ratooning were not mentioned by farmers in Zomba, which may reflect less concern about the risks of livestock due to wellestablished community-based strategies in the District.

As with pigeonpea, sorghum may be grown on soils that are marginal for maize. We encountered more sorghum production in Zomba than Mzimba or Kasungu. Sorghum is used locally for brewing, for porridge, and for nsima. It is also sold when yields allow. Sorghum is planted from November December and harvested from April - June. Sorghum is ratooned in March or October - November at 30-45 cm above the soil surface.

Farmers reported differing narratives on the effects of ratooning sorghum (Fig. 7). Ratooning saves seed and labor; 
Fig. 6 A histogram of farmers' reasons for fallowing in the Malawian Districts of (a) Mzimba (green), (b) Kasungu (orange), and (c) Zomba (purple) of

Mzimba. There were 8, 5, and 5 responses, respectively. A total of 18 data entries were recorded from the 48 interviews

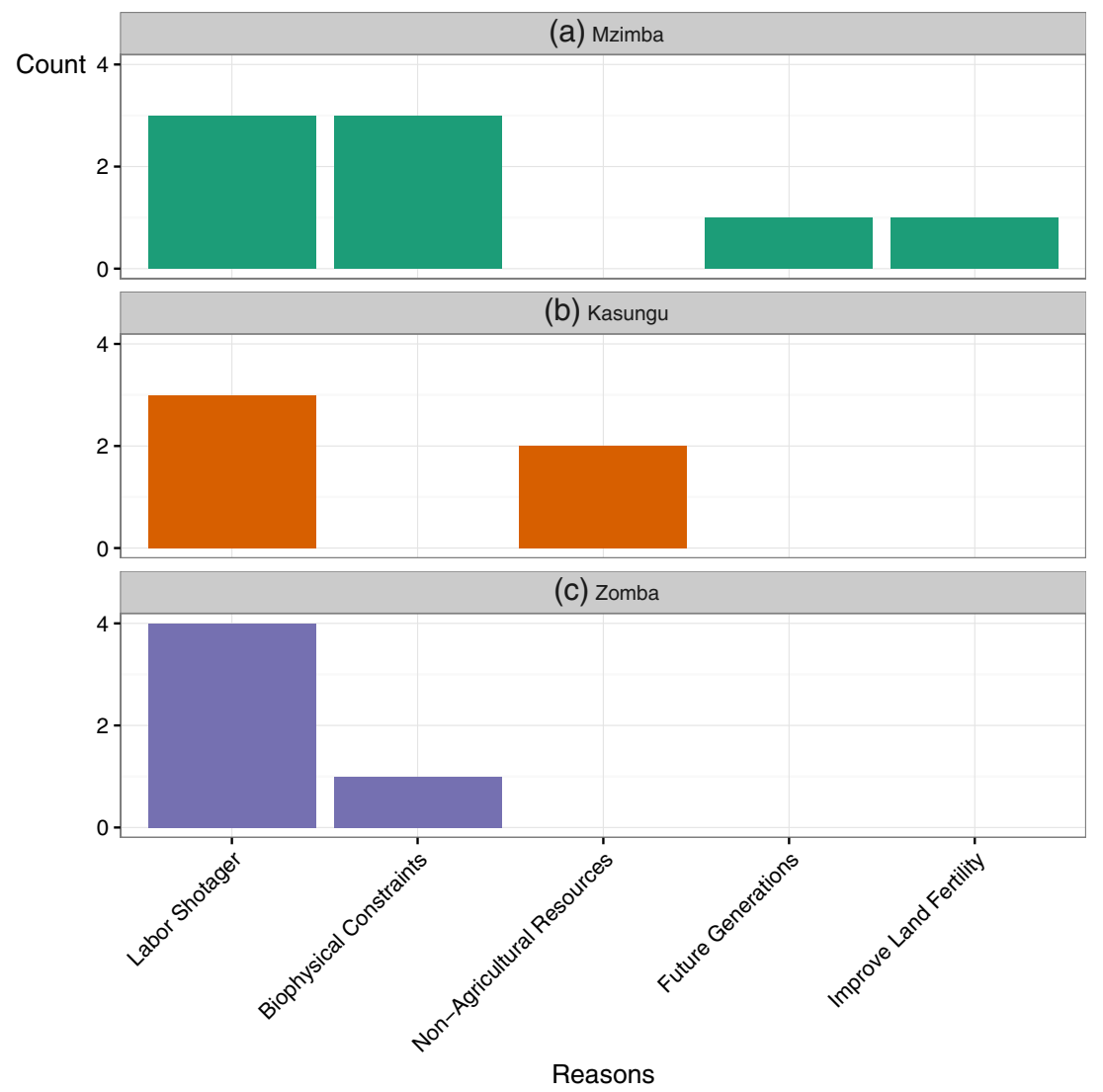

Fig. 7 A histogram of reasons why farmers choose to ratoon or not ratoon perennial staple crops in the Malawian Districts of (a) Mzimba (green), (b) Kasungu (orange), and (c) Zomba (purple). There were 4,9 , and 23

responses, respectively. A total of 36 data entries were recorded from the 48 interviews. Reasons for not ratooning were only recorded in Zomba (depicted with a $50 \%$ transparency)
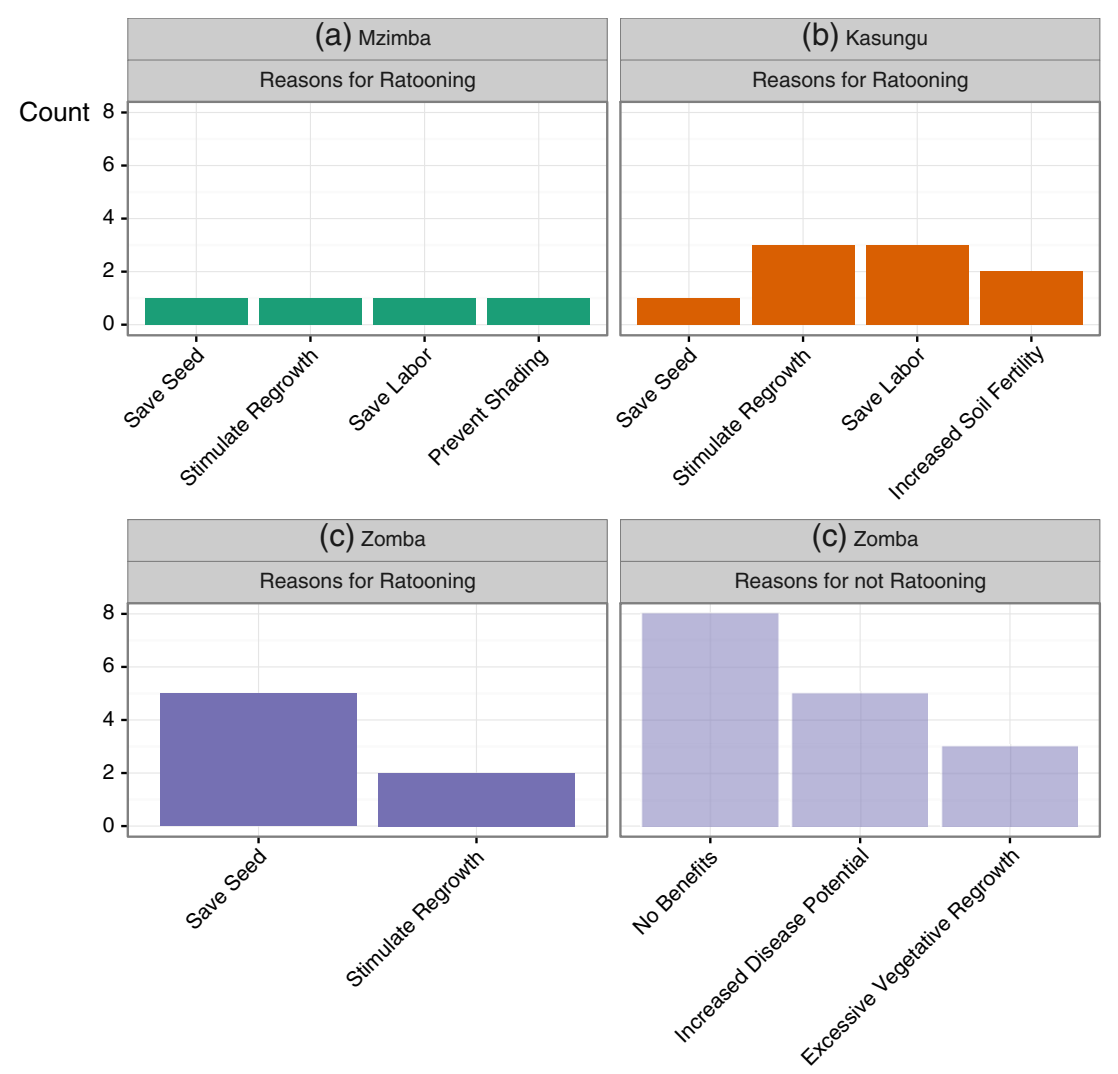

Description 
some farmers reported that ratooning produces vigorous regrowth that may increase grain yields from 50 to $150 \mathrm{~kg} /$ acre ( $30 \%$ of responses in favor of ratooning). However, others do not ratoon sorghum because it promotes diseases $(31 \%$ of responses against ratooning), particularly one called zilukhwi that a local extension worker translated as 'head smut'. Intercropping may not be possible with sorghum and maize, since the vigorous roots of ratooned sorghum reportedly occupy space and soil nutrients that ultimately suppress maize growth. Two farmers in Zomba also reported that sorghum had poor performance in rotation with maize since soil fertility may decrease.

As previously noted, we include cassava because of the functional attributes that it shares with perennial grain crops. Cassava increases food security and saves on labor. Cassava tubers may be harvested year-round, thus supplementing maize shortages in the lean months. Its leaves may also be eaten during the rainy season. Income from selling cassava may be used to buy supplemental maize. In addition to tolerating sandy soils, cassava is often planted immediately after a fallow period to loosen soils. Cassava may be planted as early as October and as late as March. The first harvest is expected to start from seven months after sowing through to the following year. Some farmers in Mzimba choose not to grow cassava because of issues with livestock damage in the dry season. However, planting cassava at the same time as maize does not dramatically increase labor demand; unlike other field crops, farmers consider ridging to be unnecessary. Growing cassava for multiple years also conserves labor.

\section{A pathway for action and research}

Based on our interviews with farmers, we propose several strategies to enhance the ecological potential of Malawian agriculture. We start by identifying useful interventions that encompass the interactions between multiple actors at the community level (Table 3). Secondly, we offer recommendations for research specifically on perennial pigeonpea, sorghum, and cassava (Table 4).

\subsection{Community level}

The scaling out of perennial staple crops will necessarily require livestock management and conflict resolution strategies. Other studies have reported that there is interest in diversifying maize production, however the potential for damage from livestock is a major barrier among a host of concerns including marketability issues, labor shortages, limited seed availability, and the potential for disease and weed problems (Ngwira et al. 2012; Zulu et al. 2015). Although we did speak with farmers who ratooned their crops, others referenced livestock grazing in the dry season as the main reason for their reluctance to grow pigeonpea and cassava for more than one season.

Participatory approaches with diverse stakeholders can improve livestock management with respect to novel crops. Farmers are interested in improving the quality of their soils, however they are not confident that new regulations will be effective. Regulations aimed at protecting perennial crops are nascent in Mzimba and Kasungu. There is distrust among the most resource-poor farmers that regulations will be enforced; the families who keep livestock are often resource-endowed and closely aligned with the village headmen who traditionally resolve disputes. Similar findings from focus groups and interviews in the Central Region identified enforcement by village headmen and emerging farmer/livestock clubs as two community based livestock management strategies currently used to avoid crop damages (Zulu et al. 2015).

Follow-up studies can help identify successful strategies for livestock management and dispute resolution. The differentiated responses we received from Zomba farmers experiencing minimal issues with crop damage from livestock supports the hypothesis made by Zulu et al. (2015) that the promise of an economic return from pigeonpea will lead to more effective social protection measures than soil fertility benefits alone. Research can help better understand the role of markets in the formation of mutually beneficial arrangements for both farmers and livestock managers.

In addition to livestock management issues, perennial staple crops present opportunities for improved fallows that increase resource provisioning and ecological benefits. It is commonly believed that long fallows on the order of 10 20 years, called traditional shifting cultivation, are today but an "anthropological curiosity" given population growth in Sub-Saharan Africa (Sanchez 1995). Nevertheless, fallows albeit of reduced duration - are still practiced in Mzimba and Kasungu. We found that fallows are used to collect fuelwood and construction materials. For places with relatively large landholdings such as Mzimba and Kasungu, improved fallows may achieve some of the same soil-improving outcomes as traditional shifting cultivation in shorter time frames (Ikerra et al. 2001). Such outcomes have been demonstrated in Malawi, Zambia and Kenya (Thangata et al. 2002). A recent study reports that improved fallows were almost twice as common in Kasungu with its large landholdings compared to Machinga in the Southern Region where farmers are more land-constrained (Quinion et al. 2010).

In places that are experiencing land-scarcity like Zomba, intercropping and relay cropping may be more commonly adopted (Quinion et al. 2010). Pigeonpea is a suitable crop for these purposes. It benefits family nutrition, supports soil rehabilitation, and produces fuelwood (Orr et al. 2015). However, the study by Orr et al. (2015) found that fuelwood collection from forests and hills continues even with the adoption of efficient stoves and with pigeonpea varieties selected 
Table 3 Action and research initiatives that have the potential to enable the scaling out of perennial staple crops in Malawi along with improvements in rural livelihoods

\begin{tabular}{|c|c|}
\hline Target & Action and Research Opportunities \\
\hline Livestock damage to perennial crops & $\begin{array}{l}\text { Identify exemplary cases of prevention and dispute resolution } \\
\text { Understand the influence of markets on enforcement of ordinances } \\
\text { Find mutually beneficial arrangements for farming } \\
\text { and animal husbandry }\end{array}$ \\
\hline Soil fertility, fallows, and conservation & $\begin{array}{l}\text { Integrate multi-use perennial staple crops (fodder, fuelwood, etc) } \\
\text { Enhance stewardship and restoration of non-agricultural lands } \\
\text { Collaboratively develop improved fallows, intercropping, } \\
\text { and relay cropping }\end{array}$ \\
\hline $\begin{array}{l}\text { Agency, family nutrition, and } \\
\text { economic development }\end{array}$ & $\begin{array}{l}\text { Organize Seed exchanges, field trials, and agroecological studies } \\
\text { Enhance the capacity of service providers to stimulate market linkages } \\
\text { Empower communities through democratic processes } \\
\text { and knowledge sharing }\end{array}$ \\
\hline
\end{tabular}

for fuelwood. The co-management model of customary lands in southern Malawi requires more study since human activity is associated with reduced biodiversity under existing economic land tenure arrangements (Mwase et al. 2006). For this reason, greater engagement is needed to leverage the interests of local people in restorative forest management practices (Davies et al. 2010).

Generally speaking, the focus of extension on staple grains has a weak correlation with nutritional outcomes for the rural poor and an emphasis on developing cash crops often accentuates gender inequality as commercialization may shift horticultural production from women to men (Fanzo et al. 2015). In Malawi, most efforts go toward maize, which is the dominant food and economic crop (Snapp 2004). This emphasis on maize also comes from farmers, who measure food shortage in terms of maize. However, farmers produce numerous other crops in different forms of association (intercropping, relay cropping, etc). These associated crops play important ecological roles, support better family nutrition, and enhance food security by providing food in the lean months. We found that farmers were interested in seed exchanges, field trials, and agronomic advice on associated crops.
The quality of agricultural extension services to farmers influences the adoption of associated crops, from supporting improvements in management practices to strengthening market linkages (Kassie et al. 2015; Snapp 2004). Evidence supports that market access and on-farm crop diversity are linked to dietary diversity in Malawi (Jones et al. 2014; Snapp and Fisher 2015), which can be achieved by various means, including more education, increased incomes, and improved crop storage technologies (Snapp and Fisher 2015). A focus on agroecology, empowerment, and gender issues has benefited the well-being and health of rural families in Malawi (Patel et al. 2015). For example, creating spaces for inter-generational knowledge exchange can foster positive behavior for better childhood nutrition (Satzinger et al. 2009). It is important to enhance the capacity of local promoters, agricultural extensionists, and researchers in participatory approaches.

\subsection{Crop-specific research needs}

We present research needs for pigeonpea, sorghum, and cassava in Malawi. Families grow pigeonpea as a perennial for up to three years through the cultural practice of ratooning. In Mzimba
Table 4 Crop-specific action and research initiatives for pigeonpea, cassava, and sorghum in Malawi

\begin{tabular}{|c|c|}
\hline Perennial Crop & Action and Research Opportunities \\
\hline Pigeonpea & $\begin{array}{l}\text { Systems research that explores multi-use crops and agroecological interactions } \\
\text { Studies on mutualistic integration of livestock with perennial pigeonpea production } \\
\text { Breeding for perennial, biofuel, and ratoon types of pigeonpea } \\
\text { Comparative study of trade-offs between types of pigeonpea for rainfed farming systems }\end{array}$ \\
\hline Sorghum & $\begin{array}{l}\text { Study disease management of ratooned sorghum } \\
\text { Study the suitability of perennial sorghum in Malawi with varietal trials } \\
\text { Assess the multi-year impacts of perennial sorghum on soil quality }\end{array}$ \\
\hline Cassava & $\begin{array}{l}\text { Develop market linkages and increase investments in processing facilities } \\
\text { Study the agroecological use of cassava, such as to loosen soils after fallows }\end{array}$ \\
\hline
\end{tabular}


and Kasungu pigeonpea now extends beyond the communities that were directly involved in the initial introductions by research projects and development initiatives. Extensionists played an important role in this process. Pigeonpea is highly valued as a perennial for improving soil quality and providing a source of fuelwood. The price for pigeonpea in Mzimba and Kasungu is low and for most families it is not a cash crop. Rather, it is grown to improve soil fertility and as a food crop. The importance of perennial pigeonpea is framed by farmers in terms of improved maize growth and yield potential with reduced dependency on fertilizer inputs.

Beyond soil improvement potential, ratooning is commonly practiced for market-oriented production of pigeonpea in Zomba because of improved yields that are obtained in subsequent years. This concurs with research from Nigeria, which found that biomass and grain yields from dwarf pigeonpea ratooned for three years was 3-6 times more productive than annually sown pigeonpea (Tayo 1985). However, positive outcomes from ratooning may be very highly site-specific since research from India attributed decreases in yields to ratoon height and soil type (Venkataratnam and Sheldrake 1985). The market price for pigeonpea is high in Zomba, especially with the expansion of export to Indian markets. In our three study areas, pigeonpea interactions with animals are communicated as a negative association due to crop damage. However, there is also the potential for positive outcomes by using pigeonpea as a forage crop.

Formal extension channels are unable to effectively give farmers advice on ratooning due to the limited published research from southern and eastern Africa. Even globally, a recent publication by the Legume Society (2016) hardly mentions ratooning. Our research demonstrates a clear case of farmer innovation to enhance the benefit of soil quality from pigeonpea. Development organizations initially introduced pigeonpea as an annual crop in 1999, however farmers experimented with ratooning the crop for 2-3 years (Snapp, Unpublished). As farmers gained experience, they switched from an annual to perennial production model. This was a surprising outcome, since ratooning is not described as a recommended practice by Malawi's Ministry of Agriculture (2012).

Perennial grains breeding is highly contested and suffers from a lack of investment. Some past investments have been made by the International Crops Research Institute for the Semi-Arid Tropics (ICRISAT) to improve pigeonpea for ratooning systems in India (Reddy and Raju 1997b), as well as in southern and eastern Africa (Gwata and Silim 2009). However, there is evidence that the priorities of African farmers for long-duration and biofuel types of pigeonpea that are conducive to ratooning are not currently on the agenda of the world's foremost public pigeonpea research centers. A recent ICRISAT (2015) workshop with African seed companies identified the following priorities for pigeonpea breeding:
"Improved pigeonpea hybrids and their seed production; New plant type concept on improvement of erect varieties and parental lines; Expansion and promotion of super-early pigeonpea genotypes in new niches."

Two out of the three of the stated priorities explicitly focus on ultra-early maturing and erect types. There may be unanticipated trade-offs by pursuing such research agendas. Ratooned pigeonpea offers the advantage of higher yields and greater nitrogen fixation in subsequent years (Snapp and Silim 2002), in addition to labor savings and reduced insect damage when intercropped with maize (Dasbak et al. 2012). More research is needed to evaluate trade-offs between ratooned and annual pigeonpea in rainfed farming systems with variable climatic conditions.

In the case of sorghum, we found that ratooning is not a widely accepted practice in Zomba where it is most commonly grown. Ratooning may promote 'head smut' due to early maturation of the grain during the rainy season. Similarly, Mbwaga et al. (1993) in a survey of diseases and pests of sorghum in Tanzania found a sporadic incidence of loose kernel smut (Sphacelotheca cruenta [Kühn]) at a late stage of development at two research stations, particularly on ratooned sorghum and secondary tillers. Additionally, ratooned sorghum provides overwintering sites for stalk borers (Kfir 1997). Still, in Ethiopia, a survey found that $30 \%$ of farmers ratooned sorghum for animal feed, food, and fuelwood (Mekbib 2009). This indicates that the early maturity of ratooned sorghum may be useful in drought years but less so in normal rainfall years.

Moreover, farmers are concerned about issues of incompatibility of ratooned sorghum in association with maize, which is the priority crop for farmers. Impacts of ratooning sorghum on soil fertility and grain yield remain unclear. There is the potential to expand the area under sorghum cultivation since farmers in Kasungu and Mzimba expressed an interest in sorghum trials. Current information is needed on the agronomic aspects of ratooning (Mekbib 2009), such as the observations provided by a Brazilian study by Foloni et al. (2008) that outlines specific cutting practices and fertility management strategies depending on whether the objective for the ratoon crop is forage or grain.

Very little research has been devoted to sorghum in Malawi, despite its historic role in staving off famine. One study from northern Malawi found that sorghum was replaced by maize due to policies that promoted hybrid maize and fertilizer inputs, as well as due to male outmigration over the last two decades that have affected the availablity of labor for defending sorghum from birds (Bezner Kerr 2014). Still, perennial sorghum may be successful in Malawi if breeding efforts improve resistance to birds (see Bullard and York 1996; Dykes and Rooney 2006) and to grain molds (see ICRISAT 2015). In the case of pigeonpea however, international breeders have largely communicated an agenda aimed at industrial compatibility that 
includes specialized plant types to accommodate larger plant populations for mechanical harvesting (ICRISAT 2015).

In addition to its labor savings and multiple harvestable products, sorghum may offer ecological benefits to smallholder farming systems in Africa. Sorghum is a good candidate for preventing soil erosion due to its extensive root system and compatibility with ratooning over multiple years. However, Reynolds et al. (2015) state that sorghum and millets may have a negative environmental impact in Sub-Saharan Africa even though there is relatively little research on the topic.

Finally, we found that limited markets for cassava exist in Mzimba and Kasungu. Farmers were interested in developing markets, such as linking with starch processors. Cassava improves family nutrition in the lean months for maize and it tolerates marginal soil conditions. Additionally, cassava is used by farmers to loosen soils immediately after fallows. For further reference, see the characterization by Chipeta and Bokosi (2013) of cassava production in Malawi along with their suggestions for future research and development.

\section{Conclusion}

Our review of the literature on perennial staple crops brings up issues that require support for near-term impact and long-term development. Increased investment is needed for breeding and agroecological research on perennial staple crops. Breeding efforts should aim to stabilize yields from ratoon crops of both sorghum and pigeonpea, as well as identify varietal adaptability and cropping arrangements suited to local conditions. The challenges of increased disease and pest incidence in ratoon crops, particularly sorghum, is needed. We did not identify sufficient documentation on whether C. partellus is contributing to the abandonment of ratooned sorghum in southern and eastern Africa. Some studies that we reviewed, as well as reports from farmers, suggest that resistant genotypes to diseases and pests can result in highly productive ratoon systems. Additionally, more studies are needed that evaluate trade-offs between the multi-year productivity of the crops in this study when managed in ratooned and annual systems. Such actions may stimulate greater support for farmer innovations that include perennial staple crops.

As has been highlighted by both the literature review and semi-structured interviews with farmers, ratooned sorghum and pigeonpea are flexible risk management strategies already used by farmers. However, according to our study, participatory onfarm research on ratooning systems has yet to occur in southern and eastern Africa or beyond. In times of persistent labor shortages in much of the world, ratooning offers farmers a way to increase their productivity with minimal additional effort. Onfarm studies are particularly important since planting densities can actually lead to decreased pigeonpea yields depending on local conditions. Moreover, limited research has studied ratooning as a water management strategy for limited resource farmers. This is particularly compelling due to the ecosystem services reported by farmers; pigeonpea and cassava are thought to improve soil fertility and rainwater infiltration.

Community-based and farmer strategies for protecting perennial grains from livestock are in their nascent stages of formation in the Northern and Central Regions of Malawi. Strengthening these initiatives will involve community engagement for the improvement of perennial food crop production. Linking farmers with emerging markets is one strategy. Finally, capacity-building with service providers can help meet farmers' interest in perennial staple crops through seed exchanges, participatory field trials, and the construction of agroecological knowledge. Research can help overcome the constraints that farmers face with respect to the broader adoption of perennial staple crops, as well as contribute to understanding of ecological and social significance.

Open Access This article is distributed under the terms of the Creative Commons Attribution 4.0 International License (http:// creativecommons.org/licenses/by/4.0/), which permits unrestricted use, distribution, and reproduction in any medium, provided you give appropriate credit to the original author(s) and the source, provide a link to the Creative Commons license, and indicate if changes were made.

\section{References}

Aguiar P (1981) Annual yield potential of grain sorghum sorghum-bicolor under irrigated conditions. Pesq Agrop Brasileira 16:117-120

Altieri M (2004) Linking ecologists and traditional farmers in the search for sustainable agriculture. Front Ecol Environ 2:35-42. doi:10.2307/ 3868293

Altieri M, Toledo V (2011) The agroecological revolution in Latin America: rescuing nature, ensuring food sovereignty and empowering peasants. J Peasant Stud 38:587-612. doi:10.1080 /03066150.2011.582947

Arunachalam L, Kulandaivelu R, Palaniappan S, Devashhayam M (1993) Effect of intercrops on yield attributes of sorghum ratoon. Madras Agric J 80:702-704

Asokaraja N, Ramiah S (1988) Parallel and relay intercropping in rainfed redgram on growth and yield. Madras Agric J 75:24-28

Balasubramaniam A, Manickasundram P (1993) Nutrient management for sorghum-sorghum ratoon system. Madras Agric J 80:718-720

Bapat D, Shinde M (1978) Grain grass sorghums for light soils of Maharashtra. Sorghum Newsl 21:44-45

Batello C, Marzot M, Touré A, Kenmore P (2004) Kreb. In: The future is an ancient lake: traditional knowledge, biodiversity and genetic resources for food and agriculture in Lake Chad Basin ecosystems. FAO, Rome, pp. $105-125$

Batello C, Wade L, Pogna N ed. et al. (2014) Perennial crops for food security. FAO, Rome

Bergquist R (1973) Colletotrichum graminicola on Sorghum bicolor in Hawaii. Plant Dis Rep 57:272-275

Bezner Kerr R (2014) Lost and found crops: agrobiodiversity, indigenous knowledge, and a feminist political ecology of sorghum and finger millet in northern Malawi. Ann Assoc Am Geogr 104:577-593. doi:10.1080/00045608.2014.892346 
Bhat K, Hosmani M (1993) Performance of ratoon as influenced by planting pattern, fertilizer levels and intercropping of cowpea in sorghum. Karnataka J Agric Sci 6:194-196

Brahmbhatt B, Patel A (1983) Role of moisture conservation practices for semi-arid condition of Gujarat. Gujarat Agric Univ Res J 8:58-66

Brown J, Howard S, Loveland Tet al (2009) ISLSCP II IGBP DISCover and SiB Land Cover, 1992-1993

Brunson M, Griffin J (1988) Comparison of rice-crayfish and grain sorghum-crayfish double cropping systems. Aqua 72:265-272. doi:10.1016/0044-8486(88)90215-3

Buchanan J (1885) The Shirè highlands (east Central Africa) as colony and mission. Blackwood, London

Bullard R, York J (1996) Screening grain sorghums for bird tolerance and nutritional quality. Crop Prot 15:159-165. doi:10.1016/0261-2194(95) $00107-7$

Calderwood M, Foale M, Radford B (1996) Management of ratooned grain sorghum in a dryland farming system. AIAS Occas Publ 327-332

Chauhan Y, Johansen C, Gupta S (1996) Assessment of ratoonability of short-duration pigeonpea genotypes. J Agric Sci 127:331-335

Chauhan Y, Venkataratnam N, Sheldrake A (1984a) The high-yield potential of extra-early pigeonpeas in peninsular India. Int Pigeonpea Newsl:28-31

Chauhan Y, Venkataratnam N, Sheldrake A (1984b) Three-season pigeonpea: a new cropping system. Int Pigeonpea Newsl:27-28

Chen M, Yein C (2005) Residual effects of rice hulls applied to sorghum fields in ratoon cultivation. J Agric Assoc China 6:142-148

Chipeta M, Bokosi J (2013) Status of cassava (Manihot esculenta) production and utilization in Malawi. Int J Agron Plant Prod 4:3637-3644

Dasbak M, Echezona B, Asiegbu J (2012) Field insect pests and crop damage assessment of pigeon pea (Cajanus cajan [L.] Huth) grown under ratoon and in mixture with maize. Chil J Agric Res 72:45-52

Davies G, Pollard L, Mwenda M (2010) Perceptions of land-degradation, forest restoration and fire management: a case study from Malawi. Land Degrad Dev 21:546-556. doi:10.1002/ldr.995

Devereux S (2002) The malawi famine of 2002. IDS Bull 33:70-78. doi:10.1111/j.1759-5436.2002.tb00046.x

Dunavin L (1975) Sorghum Alone vs. corn and sorghum in double-harvest program for silage. Soil Crop Sci Soc Fla 34:143-145

Duncan R (1979) Comparative grain yield relationships of three maturity groups of sorghum hybrids under ratoon cropping. Cereal Res Commun 7:27-32

Duncan R, Gardner W (1984) The influence of ratoon cropping on sweet sorghum yield, sugar production, and insect damage. Can J Plant Sci 64:261-274. doi:10.4141/cjps84-040

Duncan R, Miller F, Bockholt A (1980) Inheritance of tiller regrowth in ratooned sorghum. Can J Plant Sci 60:473-478. doi:10.4141/cjps80-069

Duncan R, Moss R (1987) Comparative yields of ratoon cropped temperately and tropically adapted grain sorghum hybrids. Crop Sci 27:569. doi:10.2135/cropsci1987.0011183X002700030030x

Dykes L, Rooney L (2006) Sorghum and millet phenols and antioxidants. J Cereal Sci 44:236-251. doi:10.1016/j.jcs.2006.06.007

Eldridge C (2002) Why was there no famine following the 1992 southern African drought? IDS Bull 33:79-87. doi:10.1111/j.1759-5436.2002. tb00047.x

Escalada R (1974) Tillering and ratoon cropping of grain sorghum (Sorghum bicolor (Linn.) Moench). Diss Abstr Int 34:4159-4159

European Space Agency (2000) Global land cover. http://www.esa. int/spaceinimages/Images/2005/05/GLC 2000 GLOBCOVER s predecessor. Accessed 19 Jan 2016

European Space Agency (2005) Global land cover. http://www.esa. int/spaceinimages/Images/2008/06/Earth_s land_cover. Accessed 19 Jan 2016

European Space Agency (2010) Global land cover. http://www.esa. int/spaceinimages/Images/2010/12/ESA s 2009 global land cover map. Accessed 19 Jan 2016

Fanzo J, Marshall Q, Dobermann D, et al. (2015) Integration of nutrition into extension and advisory services: a synthesis of experiences, lessons, and recommendations. Food Nutr Bull 36:120-137. doi:10.1177/ 0379572115586783

Ferguson R, Lovell S (2014) Permaculture for agroecology: a review. Agron Sustain Dev 34:251-274. doi:10.1007/s13593-013-0181-6

Foale M, Carberry P (1996) Sorghum in the farming system: Reviewing performance, and identifying opportunities by doing on-farm research. AIAS Occas Publ 63-77

Foloni J, Tiritan C, Calonego J, Dundes L (2008) Rebrota de soqueiras de sorgo em função da Altura de corte e da adubação nitrogenada. Rev Ceres 55:102-108

Gaikwad C, Jadhav A, KALBHOR P (1984) Comparative performance of ratooning vs. planting of sorghum hybrids and cultivar Maldandi-35-1 under rainfed conditions. J Maharashtra Agric Univ 9:147-149

Goodroad L, Duncan R (1988) Nitrogen fertilizer management of ratooned grain sorghum. J Plant Nutr 11:209-216. doi:10.1080/0190416 8809363796

Gwata E, Silim S (2009) Utilization of landraces for the genetic enhancement of pigeonpea in eastern and southern Africa. J Food Agric Environ 7: 803-806

Haacker M (2002) The economic consequences of HIV/AIDS in southern africa. Social Science Research Network, Rochester

Harlan J (1989a) Wild grass seed harvesting in the Sahara and sub-Sahara of Africa. In: Harris D, Hillman G (eds) Foraging and farming: the evolution of plant exploitation. Unwin Hyman, London, pp. 79-98

Harlan J (1989b) The tropical african cereals. In: Harris D, Hillman G (eds) Foraging and farming: the evolution of plant exploitation. Unwin Hyman, London, pp. 335-343

Huang H, Tsai Y, Huang S (1992) The effects of application of pig manure on the growth and yield of upland crops. Bull Taichung Dist Agric Improv Stn 19-26

ICRISAT (2015) An exercise in demand-driven research: HPRC consultation meeting

Ikerra S, Maghembe J, Smithson P, Buresh R (2001) Dry-season sesbania fallows and their influence on nitrogen availability and maize yields in Malawi. Agrofor Syst 52:13-21. doi:10.1023/A:1010772520991

Jang C, Vencill W, Paterson A, et al. (2006) Functional classification, genomic organization, putatively cis-acting regulatory elements, and relationship to quantitative trait loci, of sorghum genes with rhizome-enriched expression. Plant Physiol 142:1148-1159. doi:10.1104/pp.106.082891

Johansen C, Chauhan Y, Gupta S, Taylan F (1991) Assessing short-duration pigeonpea for multiple-harvest potential. Int Pigeonpea Newsl 15-17

Jones A, Shrinivas A, Bezner-Kerr R (2014) Farm production diversity is associated with greater household dietary diversity in Malawi: findings from nationally representative data. Food Policy 46:1-12. doi:10.1016/j. foodpol.2014.02.001

Kane D, Rogé P, Snapp S (2016) A systematic review of perennial staple crops literature using topic modeling and bibliometric analysis. PLoS One 11:e0155788. doi:10.1371/journal.pone.0155788

Kanyama-Phiri G, Snapp S, Wellard K (2000) Towards integrated soil fertility management in Malawi: Incorporating participatory approaches in agricultural research. http://www.iied.org/pubs/pdfs/7422IIED.pdf. Accessed 12 Jan 2016

Kassie M, Teklewold H, Jaleta M, et al. (2015) Understanding the adoption of a portfolio of sustainable intensification practices in eastern and southern Africa. Land Use Policy 42:400-411. doi:10.1016/j. landusepol.2014.08.016

Kfir R (1997) Competitive displacement of Busseola fusca (Lepidoptera: Noctuidae) by Chilo partellus (Lepidoptera: Pyralidae). Ann Entomol Soc Am 90:619-624

Kfir R (1992) Seasonal abundance of the stem borer Chilo partellus (Lepidoptera: Pyralidae) and its parasites on summer grain crops. J Econ Entomol 85:518-529

Kfir R, Bell R (1993) Intraseasonal changes in populations of the African stem borer Busseola fusca (fuller) (Lepidoptera; Noctuidae) and its parasitoids in Natal, South Africa. J Afr Zool 107:543-553 
Legume Society (2016) Developing a crop for the developing world: Advances in pigeonpea research

Lomte M, Dabhade R (1990) Ratoon management in grain sorghum (Sorghum bicolor). Indian J Agric Sci 60:173-176

LP DAAC (2000a) MODIS land surface temperature (MOD13Q1). https://lpdaac.usgs.gov/dataset_discovery/modis/modis_products table/mod13q1. Accessed 19 Jan 2016

LP DAAC (2000b) MODIS land cover type (MOD13Q1). https://pdaac. usgs.gov/dataset_discovery/modis/modis_products_table/mcd12q1. Accessed 19 Jan 2016

Mackenzie D, Basinski J, Parbery D (1970) The effect of varieties, nitrogen and stubble treatments on successive cycles of grain and forage sorghums in the Ord River valley. Aust J Exp Agric 10:111-117

Mahale S, Salunkhe C, Bonde R, Attarde D (1997) Effects of methods of ratooning and fertilizer levels on productivity of red gram (ICPL-87). J Maharashtra Agric Univ 21:196-198

Maheshwari S, Sharma R, Gangrade S (1997) Performance of palmarosa (Cymbopogon martini Var. motia) and pigeonpea (Cajanus cajan) intercropping under different planting geometries. Indian J Agron 42: 425-428

MASDAP (1990) Malawi Landcover Scheme II. http://www.masdap. mw/layers/geonode:malawi landcover 1990 schema 2. Accessed 3 Feb 2016

MASDAP (2000) Malawi Landcover Scheme II. http://www.masdap. mw/layers/geonode:malawi_landcover_2000_schema_2. Accessed 3 Feb 2016

MASDAP (2010) Malawi Landcover Scheme II. http://www.masdap. mw/layers/geonode:malawi_landcover_2010_schema_2. Accessed 3 Feb 2016

Mbwaga A, Pande S, De Milliano W, Karunakar R (1993) Diseases and parasitic weeds of sorghum in Tanzania: occurrence and incidence, 1986-1990. Crop Prot 12:183-188. doi:10.1016/0261-2194(93)90106-S

Mekbib F (2009) Farmers' breeding of sorghum in the Centre of diversity: Ethiopia: I. Socio-ecotype differentiation, varietal mixture and selection efficiency. Maydica 54:25-37

Messina J, Adhikari U, Carroll J ed. et al. (2014) Population growth, climate change and pressure on the land: eastern and southern Africa. Michigan State University, East Lansing

Ministry of Agriculture (2012) Guide to agriculture. Lilongwe

Molina A, Cabangbang R, Quintana R (1977) Ratoon performance of selected grain sorghum varieties at three levels of plant population and nitrogen fertilization. Philipp J Crop Sci 2:109-125

Mote U (1983) Relative damage due to major pests and losses caused by them on kharif, ratoon and rabi sorghum. Pestic 17:19-20

Mote U, Bapat D, Shirole S, Murti T (1982) Estimation of losses caused by major pests in main and ratoon crops of sorghum. Indian J Plant Prot 9: $50-55$

Mulwafu W (2011) Conservation song: a history of peasant-state relations and the environment in Malawi, 1860-2000. White Horse, Cambridge

Mwase W, Bjørnstad Å, Bokosi J, et al. (2006) The role of land tenure in conservation of tree and shrub species diversity in miombo woodlands of southern Malawi. New For 33:297-307. doi:10.1007/s11056-0069029-0

Ngwira A, Kabambe V, Kambauwa G, et al. (2012) Scaling out best fit legume technologies for soil fertility enhancement among smallholder farmers in Malawi. Afr J Agric Res 7:918-928

Nimbole N (1997) Maximum yield and survival of perennial pigeonpea (Cajanus cajan) by improving planting site, watering and chemicals. Indian J Agric Sci 67:507-509

NRC (1996) Lost crops of Africa: grains. National Academy, Washington, DC

Orr A, Kambombo B, Roth C, et al. (2015) Adoption of integrated foodenergy systems: improved cookstoves and pigeonpea in southern Malawi. Exp Agric 51:191-209. doi:10.1017/S0014479714000222

Pal M, Kaushik S (1969) A note on ratooning of sorghum in northern India. Indian J Agron 14:296-298
Pandey N, Singh N (2000) Ratoon feasibility of long-duration pigeonpea hybrids. International Chickpea and Pigeonpea Newsl 47-49

Parmornchantr P (1966) Grain sorghum growing and advantage of ratoons in making selection. Kasikorn 39:373-382

Patel B, Patel K, Joshi RS, Raman S (1989) Scheduling irrigation in ratoon sorghum on the basis of critical stages. Gujarat Agric Univ Res J 14:1-6

Patel R, Bezner Kerr R, Shumba L, Dakishoni L (2015) Cook, eat, man, woman: understanding the new alliance for food security and nutrition, nutritionism and its alternatives from Malawi. J Peasant Stud 42:21-44. doi: $10.1080 / 03066150.2014 .971767$

Pawar H, Thaval D (1984) Comparative performance of ratoon sorghum sorghum-bicolor and wheat Triticum-Aestivum grown after kharif sorghum intercropped with cowpea Vigna-Sinensis. J Maharashtra Agric Univ 9:72-74

Quinion A, Chirwa P, Akinnifesi F, Ajayi O (2010) Do agroforestry technologies improve the livelihoods of the resource poor farmers? Evidence from Kasungu and Machinga districts of Malawi. Agrofor Syst 80:457-465. doi:10.1007/s10457-010-9318-7

Ramshe D, Surve D, Patil B (1985) Production potential and economics of multiple cropping systems. J Maharashtra Agric Univ 10:312-314

Rao D, Damodaram G (1972) Preliminary studies on ratooning in sorghum varieties and hybrids. Madras Agric J 59:301-303

Reddy M, Raju T (1997a) Evaulation of pigeonpea (Cajanus cajan) varieties for resistance to wilt caused by fusarium udum and sterility mosaic disease in a perennial system. Indian J Agric Sci 67:437-439

Reddy M, Willey R (1985) Evaluations of alternate cropping systems for Alfisols of the Indian semi-arid tropics. Exp Agric 21:271-280. doi:10.1017/S001447970001262X

Reynolds T, Waddington S, Anderson C, et al. (2015) Environmental impacts and constraints associated with the production of major food crops in sub-Saharan Africa and South Asia. Food Secur 7:795-822. doi:10.1007/s12571-015-0478-1

Sanchez P (1995) Science in agroforestry. Agrofor Syst 30:5-55. doi:10.1007/BF00708912

Satzinger F, Bezner Kerr R, Shumba L (2009) Intergenerational participatory discussion groups foster knowledge exchange to improve child nutrition and food security in northern Malawi. Ecol Food Nutr 48:369 382. doi:10.1080/03670240903170483

Saxena K, Sharma D, Green J (1976) Pigeon pea ratooning: an aid to breeders. Trop Grain Legum Bull 21-21

Sharma D, Saxena K, Green J (1978) Potential of ratooning in pigeonpea. Field Crop Res 1:165-172. doi:10.1016/0378-4290(78)90019-9

Snapp S (2004) Innovations in extension from Malawi. Hort Technol 14: $8-13$

Snapp S, Blackie M, Gilbert R, et al. (2010) Biodiversity can support a greener revolution in Africa. Proc Natl Acad Sci 107:20840-20845. doi:10.1073/pnas.1007199107

Snapp S, Fisher M (2015) "filling the maize basket" supports crop diversity and quality of household diet in Malawi. Food Secur 7:83-96. doi:10.1007/s12571-014-0410-0

Snapp S, Silim S (2002) Farmer preferences and legume intensification for low nutrient environments. Plant Soil 245:181-192. doi:10.1023/A: 1020658715648

Stinson D, Arkin G, Howell T (1981) Modeling grain sorghum ratoon cropping and associated runoff and sediment losses. Trans ASAE 24: 631-635

Subramanian P, Purushothaman S, Pechiappan S (1986) Irrigation management for ratoon sorghum. Madras Agric J 73:389-393

Tayo T (1985) Assessment of the effect of ratooning pigeon pea (Cajanus cajan (1.) millsp.) in the lowland tropics. J Agric Sci 104:589-593. doi:10.1017/S0021859600044361

Thangata P, Hildebrand P, Gladwin C (2002) Modeling agroforestry adoption and household decision-making in malawi

Touchton J, Martin P (1981) Response of ratooning grain-sorghum to nitrogen-fertilizer and insecticides. Agron J 73:298-300. doi:10.2134/ agronj1981.00021962007300020013x 
Vaughan M (1987) The story of an African famine: gender and famine in twentieth-century Malawi. Cambridge Univ, New York

Venkataratnam N, Sheldrake A (1985) Second harvest yields of medium duration pigeonpeas (Cajanus cajan) in peninsular India. Field Crop Res 10:323-332. doi:10.1016/0378-4290 (85)90038-3

Wade L, Douglas A, Foreman J (1992) Agronomic measures to minimise limitations to grain yield of irrigated and ratooned grain sorghum. AIAS Occas Publ 423-433

Yadav N, Yadav D (1991) Second harvest yield of pigeonpea as influenced by different varieties and plant population density. Indian J Pulses Res 4:117-119
Yadav N, Yadav D (1992) Production potential and economic returns of different pigeonpea (Cajanus-Cajan)-based cropping systems as influenced by variety and plant-population. Indian J Agron 37:430-435

Yadava N, Yadav D (1995) Comparative performance of different cropping systems based on pigeonpea (Cajanus-Cajan). Indian J Agric Sci 65: 106-108

Zulu L, Adams E, Chikowo R, Snapp S (2015) Emergence of communitybased livestock management institutions to control herbivory for promoting scaling up of pigeon peas in legumes/maize systems in central and southern Malawi. Michigan State University 